\title{
Merger control for IRPs: Do acquisitions of distressed firms warrant competition scrutiny?
}

\author{
M. P. Ram Mohan \\ Vishakha Raj
}

W. P. No. 2020-05-02

May 2020

The main objective of the working paper series of the IIMA is to help faculty members, research staff and doctoral students to speedily share their research findings with professional colleagues and test their research findings at the pre-publication stage. IIMA is committed to maintain academic freedom. The opinion(s), view(s) and conclusion(s) expressed in the working paper are those of the authors and not that of IIMA.

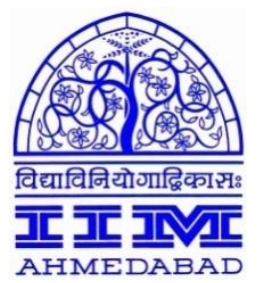

INDIAN INSTITUTE OF MANAGEMENT

AHMEDABAD-380 015

INDIA 


\title{
Merger control for IRPs: Do acquisitions of distressed firms warrant competition scrutiny?
}

\author{
M. P. Ram Mohan* \& Vishakha Raj**
}

\begin{abstract}
:
In July 2019, the Competition Law Review Committee Report had recommended that Insolvency Resolution Plans (IRP) which result in combinations should be green-channelled. This would mean that IRP combinations would be automatically approved without any merger scrutiny. The theoretical basis of this recommendation is the 'failing firm defence' which allows parties to enter into mergers if they show that the exit of a firm from the market will be more harmful to competition than the merger. This paper assesses the advisability of greenchannelling IRPs through the lens of competition law. It examines the IRPs which have been scrutinised by the CCI and examines whether they are treated differently from other mergers. We use the European Union as a point of comparison to describe how the failing firm defence is being implemented and to show that there can be anticompetitive effects to green-channelling IRPs without a full competition assessment. We conclude that while the failure of a firm is an important consideration when assessing mergers, it cannot be the sole determinant of their desirability.
\end{abstract}

Keywords: Insolvency and bankruptcy in India, green-chanelling, failing firm defence, competition, insolvency resolution plans

JEL classification: F23, K2, K10, K21

\footnotetext{
* Associate Professor, Business Policy Area, Indian Institute of Management Ahmedabad and Member, Misra Centre for Financial Markets and Economy at IIMA (mprmohan@iima.ac.in).

** Researcher, Business Policy Area, Indian Institute of Management Ahmedabad.

We are grateful to the Insolvency and Bankruptcy Board of India (IBBI) in supporting this study under "the IBBI Research Initiative, 2019". The authors wish to thank the anonymous reviewer and Praachi Misra, whose comments greatly helped us in improving the clarity of analysis. All errors are our own. This working report is submitted to IBBI on 05 May 2020 and is available also at https://www.ibbi.gov.in/.
} 


\section{Contents}

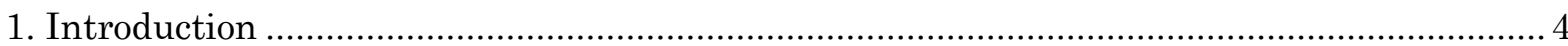

2. Interface between the objectives of insolvency and competition law ................................... 6

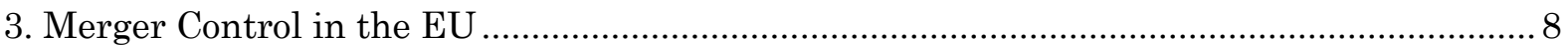

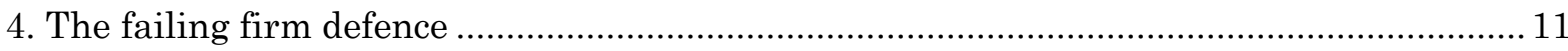

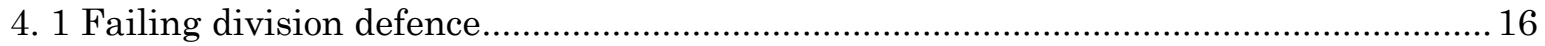

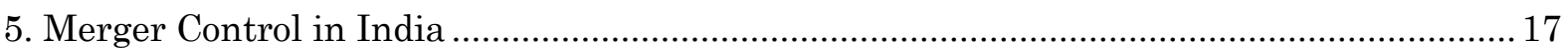

6. The UK's Competition and Markets Authority - A voluntary merger regime ..................... 18

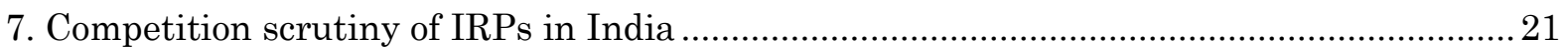

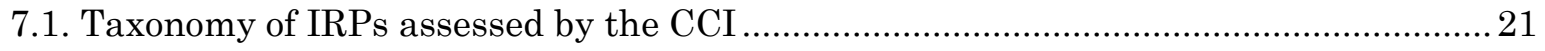

7.2. Limitations of 'creditors' wisdom' in the insolvency resolution process ........................25

7.3. The NCLAT: an institutional bridge between merger control and insolvency law ......27

8. Merger control: its relevance in competition regimes and effects on insolvency regimes. . 28

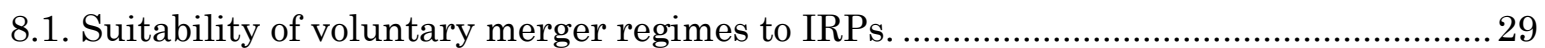

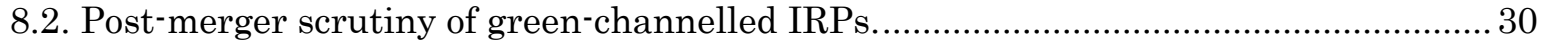

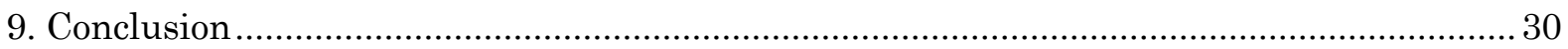

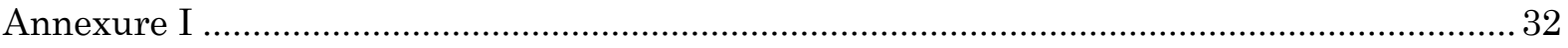

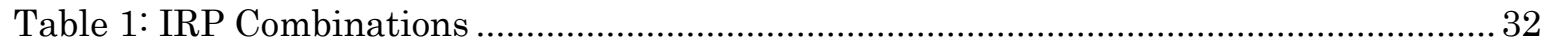

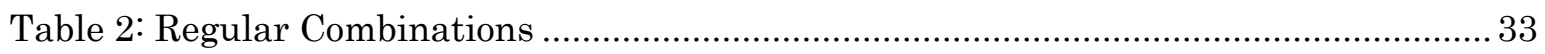




\section{Introduction}

In July 2019, the Competition Law Review Committee submitted its report to the Ministry of Corporate Affairs (the Report), recommending a 'Green Channel' for merger approvals by the Competition Commission of India. ${ }^{1}$ The Report proposed that Insolvency Resolution Plans (IRP) should automatically qualify for the Green Channel. This would mean that the IRPs will not be scrutinised by the Competition Commission of India (CCI) even if they cross the thresholds mentioned in the CCI's Combination Regulations framed under the Competition Act, $2002 .^{2}$

On $13^{\text {th }}$ August, 2019, the Green Channel was created through the CCI (Procedure in regard to the transaction of business relating to combinations) Amendment Regulations, 2019 (Combination Regulation Amendment). However, the Combination Regulation Amendment has not extended green-channelling to IRPs. Despite this, it is worth discussing green channelling in the context of IRPs as the Government may choose to implement the Report's recommendation to green channel IRPs in the future.

In a nutshell, the Green Channel is a self-certifying mechanism by which mergers that meet certain criteria will be automatically approved. The objective of this recommendation, as stated in the Report, was to reduce the transaction costs associated with mergers which are unlikely to cause an Appreciable Adverse Effect on Competition (AAEC). The Report cited the low rates of modification for notified mergers between 2011 and 2018 (2.6 per cent) as a reason for its recommendation. ${ }^{3}$ So far, there have been sixteen IRPs which have been scrutinised by the CCI. Even without a Green Channel being in place for IRPs, all of the sixteen IRP combinations have been approved.

The amended Combination Regulations green-channel mergers with no horizontal or vertical overlaps (conglomerate mergers). ${ }^{4}$ There will be no standstill period for mergers which have gone through the green channel (other mergers have a standstill period of 210 days, before

\footnotetext{
${ }^{1}$ Ministry of CoRporate AfFaiRs, RePort of the Competition LaW Review CommitTeE (July 2019), 127, http://www.mca.gov.in/Ministry/pdf/ReportCLRC_14082019.pdf.

${ }^{2}$ Competition Act, No. 12, Acts of Parliament, $2003 \S 5$,

https://www.cci.gov.in/sites/default/files/cci_pdf/competitionact2012.pdf.

${ }^{3}$ REPORT OF THE COMPETITION LAW REVIEW COMMitTEE, supra note 1, ๆ 4.44

${ }^{4}$ Competition Commission of India (Procedure in regard to the transaction of business relating to combinations) Amendment Regulations, 2019, F.No. CCI/CD/Amend/Comb. Regl./2019, Regulation 2, https://www.cci.gov.in/sites/default/files/notification/210553.pdf
} 
which a merger cannot be completed, unless it is approved earlier by the CCI). Firms decide whether or not they meet the criteria to qualify for the green channel. If firms have provided incorrect information or misrepresented facts to qualify for the green channel, the consequent merger will be deemed to have been void ab-initio. ${ }^{5}$

India has a suspensory merger control regime because merger transactions are effectively suspended until CCI approval or the end of the standstill period. ${ }^{6}$ Green-channelling removes the suspensory nature of the Indian merger regime by doing away with the standstill period. This moves India closer to voluntary merger regimes which are in place in jurisdictions such as New Zealand, the United Kingdom (UK), and Australia. ${ }^{7}$ Voluntary regimes face unique challenges when it comes to merger enforcement, the implications of these challenges have been discussed in the context of the Report's recommendation for green channelling IRPs later in the paper.

The theoretical basis for green-channelling IRPs is the failing firm defence, which is a set of tests used to determine whether an otherwise anti-competitive merger should be approved due to the imminent failure of a firm in the absence of the merger. This defence has been used to justify green-channelling IRPs. The argument in favour of this is that by virtue of the IRP having gone through the insolvency resolution process, it can be assumed that the requirements of the defence have been met. ${ }^{8}$ Such reasoning is problematic because neither the Competition Act, 2002 nor the Combination Regulations detail how the failure of a firm is to be assessed in the context of merger control. Section 20 of the Competition Act mentions 'possible failure of business' as a factor that can be considered by the CCI while assessing a merger, ${ }^{9}$ but there is no indigenous guidance on how this factor is to be applied. Other jurisdictions have developed guidelines to apply the failing firm defence. While different jurisdictions use their own approaches to apply the defence, the tests comprising it are broadly as follows, whether the failure of the firm is imminent in the absence of the merger, whether there is an alternative entity which can merge with or acquire the failing firm resulting in a

\footnotetext{
${ }^{5} I d$.

${ }^{6}$ Aditi Gopalkrishnan, Gaurav Bansal, Rahul Shukla, \& Karan Sood, India: Merger Control, AZB \& PARTNERS (JAN. 07, 2020). HTTPS://WWW.AZBPARTNERS.COM/BANK/INDIA-MERGER-CONTROL-4TH-EDITION/

${ }^{7}$ Christ Boyd, 'Gun-jumping' in voluntary merger regimes: The risks keeping global transactions in suspense, KLUWER COMPETITION LAW BLOG (Oct. 24, 2019).

http://competitionlawblog.kluwercompetitionlaw.com/2019/10/24/gun-jumping-in-voluntary-merger-regimesthe-risks-keeping-global-transactions-insuspense/?doing_wp_cron=1584286873.4761159420013427734375\#_ftn1

${ }^{8}$ Divyansh Dev, Competition Act and Insolvency \& Bankruptcy Code: Applying the Failing Firm Defence for Green Channel Approval for cases Bar \& Bench (Feb. 23, 2020),

https://www.barandbench.com/columns/competition-act-and-insolvency-bankruptcy-code-applying-the-failingfirm-defence-for-green-channel-approval-of-cases.

${ }^{9}$ Competition Act, supra note $2, \S 20(4)(\mathrm{k})$.
} 
less anticompetitive transaction, and whether the assets of the firm would exit the market in the absence of the merger.

This paper discusses the advisability of green-channelling IRPs from a competition law perspective. The paper analyses whether the CCI's orders in the IRP combinations account for the objectives of insolvency law and whether there are differences in the CCI's approach to IRP combinations and regular combinations. It also assesses whether there are any dependable criteria that can be generated from the CCI's approach to IRP combinations that can be used to green-channel future IRP combinations.

Before delving into the CCI's orders, the paper examines the interaction between competition law (specifically merger control) and insolvency law through the failing firm defence in the context of the European Union (EU). ${ }^{10}$ Insights from cases in the EU are referred to in order to highlight the points of interface between competition and insolvency objectives and the conflicts that arise between them. We refer the United Kingdom's (UK) competition regime to highlight what is expected from the CCI if India moves closer to a voluntary merger regime.

The paper concludes with an appraisal of the Report's recommendation to green-channel IRPs and makes recommendations for allowing the objectives of both regimes to play a proportionate role in deciding the viability of an IRP.

\section{Interface between the objectives of insolvency and competition law}

Insolvency law and competition law govern different aspects of a firm's economic freedom and a market's efficiency. Competition law gives firms the freedom to operate on an even playing field and ensures that market conditions and signals are not distorted by anticompetitive practices. Insolvency laws, on the other hand, ensure that resources (especially credit) are allocated efficiently and can be reallocated to more efficient uses when required. ${ }^{11}$ After the enactment of the IBC, when a firm is unable to pay its debts, insolvency law allows the firm to come to an agreement with its creditors and subsist as a going concern. ${ }^{12}$ If this approach

\footnotetext{
${ }^{10}$ The choice of the EU as a point of reference for the Indian regime is based on its pre-merger notification regime (which is similar to India's when compared to the UK) less stringent use of the defense compared to the US.

${ }^{11}$ M.S. Sahoo, Freedom to Exit: The Insolvency and Bankruptcy Code, 2016 builds the third pillar of economic freedom, INSOLVENCY AND BANKRUPTCY BOARD OF INDIA, https://ibbi.gov.in/uploads/resources/the\%20Insolvency\%20and\%20Bankruptcy\%20Code,\%202016\%20builds $\% 20$ the \%20third\%20Pillar\%20of\%20Economic \%20Freedom\%20in\%20IBBI\%20Newsletter\%20OctoberDecember\%202016.pdf

${ }^{12}$ Insolvency and Bankruptcy Code, No. 31, Acts of Parliament, 2016, Chapter 7 [Henceforth IBC]; U.S. Bankruptcy Code 11 U.S.C. (2018), Chapter 11 of US Bankruptcy Code; Insolvency Act 1986, c. 45, sch. B1 (United Kingdom).
} 
fails, insolvency law provides a means to liquidate the firm. In the first recourse, the credit in the firm is being put to more efficient use within the firm; in the second recourse, the firm is being allowed to exit the market so that the credit it once used may be freed up and put back into the market. Thus, competition law provides the freedom to operate and insolvency law provides the freedom to exit. ${ }^{13}$

Insolvency laws affect competition regimes and this has been demonstrated across different jurisdictions. Normally, insolvency law offers certain protections to a firm that is subject to insolvency proceedings. A common example of such a protection which is found in multiple jurisdictions, including India, is the operation of a moratorium on bringing proceedings to enforce contracts or recover debts against the debtor firm by creditors. ${ }^{14}$ This would also extend to enforcing burdensome contracts given that the moratorium prohibits the initiation and continuance of any new or pending legal proceedings respectively. 15 These provisions of insolvency law can give firms a competitive edge over other firms which have not initiated insolvency. ${ }^{16}$ Airline carriers in the United States (US) have often used this technique to negotiate with labour unions because they are aware that bargaining becomes easier when within the 'protective umbrella' of insolvency law. ${ }^{17}$

Another important area where insolvency law and competition law interact is merger control. Mergers and acquisitions have become an increasingly common means of restructuring financially distressed companies. ${ }^{18}$ Indian law, being aware of the possible overlap between merger control and insolvency law, requires IRPs under the IBC to conform with Sections 5 and 6 of the Competition Act. ${ }^{19}$ Sections 5 and 6 of the Competition Act deal with combination regulation and require the CCI to approve combinations that meet certain criteria, thus preventing excessive market concentration. Consequently, IRPs need to be approved by two authorities, the Adjudicating Authority under the IBC (the National Company Law Tribunal) and the CCI, if they meet the thresholds mentioned in the Competition Act.

\footnotetext{
${ }^{13}$ Sahoo, supra note 11.

14 11 U.S.C. $\$ 362$ (2018) IBC, supra note $12, \S 14$

${ }^{15}$ Id., § 14. See Christopher G. Paulus, Competition Law versus Insolvency Law: When Legal Doctrines Clash, UNIF. L. REV. 1, 9 (2013) (discussing how the US Bankruptcy Code allows debtors to reject certain contracts and avoid certain transactions).

${ }^{16} I d$.

${ }^{17}$ Paulus, supra note 15, at 9 (discussing how air carriers have used the US Bankruptcy Code to negotiate with labour unions). See Lawrence Spizman \& John Kane, Chapter 11 Bankruptcy and the Termination of Collective Bargaining Contracts, ) 3 EMP. RESP. \& RTS. J. 277, 277 (1990) (discussing the use of Chapter 11 of the US Bankruptcy Code to terminate labour contracts by airlines).

${ }^{18}$ IONNIS KOKKORIS \& RODRIGO OLIVARES-CAMINAL, ANTITRUST LAW AMIDST FINANCIAL CRISES, 103-104 (2010).)

${ }^{19} \mathrm{IBC}$, supra note $12 . \S 31(4)$.
} 
The European Commission (EC) considers the possibility of a firm becoming insolvent and the anticompetitive effects of its assets exiting the market as important factors to assess the desirability of the effects of a merger. The EC weighs the anticompetitive effects of a merger against those which will accrue if the firm is forced to declare bankruptcy as a consequence of not being able to merge with another. ${ }^{20}$ The use of this type of counterfactual analysis is what has been discussed above as the failing firm defence. Generally, a counterfactual analysis compares the post-merger market with what the market would be like without the merger i.e., the counterfactual to the merger. The failing firm defence is used in contexts where the counterfactual to the merger involves the exit of one or more firms from the market. This defence is an important theoretical foundation for discussing mergers involving distressed firms as it is the basis on which competition authorities can approve mergers of financially distressed firms even when they entail a deterioration of competition in the market. ${ }^{21}$ To successfully establish the defence, parties need to show that the effect of the merger is not worse than the effect of the target firm exiting the market. ${ }^{22}$

The failing firm defence is an exception to the general rule of merger control as it would allow competition authorities to approve mergers despite their anticompetitive effects. ${ }^{23}$ The imminent failure of the target firm is an important aspect of the failing firm defence, which is why firm's participation in insolvency proceedings can be a basis for this defence. The failing firm defence has been analysed in the context of the EU, where it evolved through case laws and was subsequently made a part of the EU Merger Guidelines. In order to fully appreciate the defence and its role in EU merger control, the EU's merger control regime has been briefly discussed below.

\section{Merger Control in the EU}

Each member of the EU has its own insolvency and competition laws and authorities. This means that each of them applies different versions of the failing firm defence when assessing the competitive effects of 'rescue' acquisitions. ${ }^{24}$ However, the EU is a single market, implying that firms (including financially distressed ones) have to be mindful of the effects their actions can have across all EU member states. The EC investigates violations in EU competition law,

\footnotetext{
${ }^{20}$ Case COMP/M.2574, Pirelli/Edizone/Olivetti/Telecom Italia., https://ec.europa.eu/competition/mergers/cases/decisions/m2574_it.pdf; See Antonio Bavasso \& Alistair Lindsay, Causation in EC Merger Control, 3 (2) J. OF COMP. L. \& ECON. 181, 189 (2007). ${ }^{21}$ KOKKORIS \& OLIVARES-CAMINAL, supra note 18 at 112.

${ }^{22} \mathrm{Id}$. at $112-113$.

${ }^{23}$ Organisation for Economic Corporation and Development (OECD), Policy Roundtables: The failing firm defence, at 11-12 (2009) https://www.oecd.org/competition/mergers/45810821.pdf [Henceforth OECD Roundtable].

${ }^{24}$ Case No. IV/M.308, Kali+Salz/MdK/Treuhand, 1993, O.J. (L 186) 38
} 
enforces orders, conducts fact finding missions and sectoral surveys, and takes legislative and policy initiatives. ${ }^{25}$ The core legislation for EU competition law is contained in the Treaty for the Functioning of the European Union (TFEU) under Chapter 1, Title VII, from Article 101 to 109. The principles contained in these Articles are implemented through various EC Regulations. Article 101 generally prohibits agreements between undertakings, decisions by associations of undertakings and concerted parties which directly or indirectly distort competition. Article 102 prohibits firms from abusing their dominant position. Article 103 of the TFEU allows the EC to formulate rules and regulations to effectuate the principles mentioned in Articles 101 and 102. The EU's Merger Regulation is a result of the general mandate in Article 103. Notably, the EU does not have any specific principles which apply to merger control in the TFEU as it does for anticompetitive agreements and abuse of dominance. ${ }^{26}$

The EU's merger control regime is detailed in EU Merger Regulation - 130/2004 (EUMR). The EUMR establishes a pre-merger notification regime like the one followed by the CCI in India prior to the 2019 Combination Regulation Amendment. Regimes that require mergers to be cleared prior to their implementation are known as 'suspensory' regimes. These regimes effectively suspend the merger until the competition authority clears it (this is the equivalent of the standstill period under the Indian Competition Act). The EUMR requires that all combinations with a 'community dimension' are notified to the EC. The idea of a 'community dimension' in the EU is akin to 'combinations thresholds' in India. Whether or not a merger has a community dimension in the EU is based on thresholds set for the value of assets held by the merging entities and their turnovers. ${ }^{27}$

After a merger is notified, the EC investigates the transaction and passes orders according to its findings. The EC may approve the merger, prohibit it, dissolve the merger (in case of premature implementation), or approve the merger with conditions that would make it compatible with the common market. ${ }^{28}$

\footnotetext{
${ }^{25}$ RICHARD WHISH \& DAVID BAILEY, COMPETITION LAW, 53 ( $6^{\text {th }}$ ed. 2011)

${ }^{26}$ Id. at 828

${ }^{27}$ A merger has a community dimension if the aggregate worldwide turnover of all the involved parties is more than EUR 5 billion and the aggregate community-wide turnover is more than EUR 250 million. If more than two-thirds of each of the concerned parties' turnover is within one and the same member state, then the community-wide turnover requirement will not be met, and the merger will not have a community dimension. If the combined worldwide turnover of the involved parties is more than EUR 2.5 billion, and they have an aggregate turnover of EUR 100 million in each of at least three member states, and the aggregate communitywide turnover of at least two of the parties is over EUR 100 million, then the merger will have a community dimension. If more than two-thirds of each of the parties' turnover is within one and the same member state, then the merger will not have a community dimension.

${ }^{28}$ Council Regulation (EC) 139/04, 2004, O.J. (L 24) 1, art. 8., Article 8
} 
The EUMR proscribes market concentrations through mergers which cause a significant impediment to effective competition by establishing or strengthening a dominant position. ${ }^{29}$ The EU Merger Guidelines detail the various factors which need to be taken into account when assessing the market effects of horizontal and non-horizontal mergers. Most mergers which are notified are likely to increase the dominance of the merged entity in the market, but this alone is not enough to declare a merger incompatible with the common market. The EC considers several factors to understand the full scope of the concentration's impact. These factors can broadly be discussed under three categories, countervailing factors, counteracting factors, and (most relevant to this paper), the likelihood of a firm's exit from the market. The first set of factors comprises market circumstances that ensure that the market remains competitive despite an increase in concentration, these are known as countervailing factors. Countervailing factors ensure that the rivalry between firms continues to exist along with their incentive to compete. The second set of factors comprises counteracting factors, these do not mitigate the anticompetitive effects of a merger but are reasons based on which the EC can approve a merger despite its anticompetitive effects.

The existence of substitutes in the market and the ability of consumers to easily change their supplier is a strong countervailing factor (countervailing buyer power). This is strengthened if other firms have the ability to increase their production to meet the demands of consumers who wish to stop buying from the merged firm. In addition to this, low barriers to entry act as an important countervailing factor, but this needs to be balanced with the ability of existing firms to keep their market shares (for instance, by offering long term-contracts or reducing prices) and barriers to entry such as legal hurdles, research and development, reputation of incumbents etc. ${ }^{30}$

Efficiency is a widely used counteracting factor when considering the effects of a merger. When examining the efficiencies generated as a result of a merger, the EC examines whether these efficiencies translate into consumer benefits. ${ }^{31}$ This usually manifests through the merged entity's ability to reduce prices by optimizing their production and distribution, benefits that are consequences of harnessing economies of scale. In addition to a reduction in prices, merged entities may have access to better research \& development, for instance, the intellectual property of one of the merged firms can now be used by both. Any increase in efficiency must

\footnotetext{
${ }^{29}$ Id. at art. 2(3).

${ }^{30}$ European Commission Guidelines on the assessment of horizontal mergers under the Council Regulation on the control of concentrations between undertakings, 2004 O.J. (C 31) 3, 12.

${ }^{31}$ Id. II 79.
} 
be causally linked to the merger. Thus, if the same increase in efficiency can be achieved by less anticompetitive means, the EC is less likely to allow the merger. ${ }^{32}$

The third category refers to a situation in which the assets of the firm would leave the market if the merger were not allowed. There are various reasons for why the assets of a firm may exist the market, for instance, this may happen if there is a change in corporate strategy. However, this paper will focus on the 'failing firm defence' which refers to situations in which a firm is likely to leave the market because of financial difficulties.

\section{The failing firm defence}

The failing firm defence is an exception to the general norm of merger control. ${ }^{33}$ Normally, the merger would be prohibited if the pre-merger competitiveness of the market were worse than its post-merger competitiveness. However, the failing firm defence can be used to decouple the post-merger state of the market from the merger. This is done by showing that the market condition is likely to deteriorate to an equal extent if the target firm were not acquired and allowed to 'fail' or exit the market. This test is applied differently across different jurisdictions; however, it is used in almost all developed economies when assessing the effects of the merger/acquisition of a firm that is financially failing. ${ }^{34}$ The imminent failure of a division of a firm was used as an argument in Aerospatiale. ${ }^{35}$ However, the EC did not expressly discuss the failing firm defence in this case. Aerospatiale is relevant for understanding the 'failing division defence' and has been discussed in the following section.

The successful use of the failing firm defence in the EU is based on three tests,

i. whether financial difficulties would force the firm out of the market,

ii. whether there exists a less anticompetitive alternative purchase/transaction that could rescue the firm, and

iii. whether the assets of the firm would exit the market in the absence of a merger.

These tests were extensively discussed by the EC for the first time in the Kali und Salz decision. ${ }^{36}$ Since then, the tests have been used in other cases where the target of a merger

\footnotetext{
${ }^{32} I d$. 1185.

${ }^{33}$ Id. III 89-91.

${ }^{34}$ KOKKORIS \& OlIVARES-CAMINAL, supra note 18, at 106; See OECD Roundtable, supra note 23, at 11-12.

${ }^{35}$ Case IV/M.053, Aerospatiale-Alenia/De Havilland, 1991 O.J. L (334) 42.

${ }^{36}$ Case No. IV/M.308,Kali+Salz/MdK/Treuhan, 1993 O.J. (L 186) 38. The case was appealed, and the EC's approach to the failing firm defense was upheld by the European Court of Justice in Case 68/94 French Republic v. Commission of the European Communities, 1998, E.C.R. I-1375.
} 
was a failing firm and they have been adopted by the EU Merger Guidelines. ${ }^{37}$ Kali und Salz was a decision concerning the acquisition of Mitteldeutsche Kali AG (MdK) by Kali und Salz, a subsidiary of chemical group BASF. Both parties were engaged in the business of producing potash and salt-based products for industrial and agricultural use. Kali und Salz and MdK had a combined market share of 98 per cent ${ }^{38}$ in the German market and 60 per cent ${ }^{39}$ in the community market for potash products. The merger also involved their magnesium sulphate producing businesses, of which Kali und Salz ${ }^{40}$ and $\mathrm{MdK}^{41}$ had a combined marker share of 90 per cent in the community market. The merger effectively conferred a monopoly status on Kali und Salz/MdK in the potash and magnesium sulphate markets. Despite strengthening Kali und Salz's dominant position, the merger was approved by the EC which used the failing firm defence to make its decision. Three tests were used to determine whether the defence could be applied.

For the first test, the EC needed to be convinced that MdK would leave the market in the near future if not for the merger. To assess this possibility, the EC looked at the economic performance of MdK. It noted that MdK was not able to produce at more than 50 per cent of its capacity for the past three years. It had been incurring large losses which were covered only because it was funded by a public sector entity (Treuhand) whose mandate was to revive and restructure the former German Democratic Republic's public sector businesses and ultimately, privatize them. ${ }^{42}$ However, the EC noted that Treuhand was unlikely to continue supporting MdK, especially because its support was likely to contravene the EC Treaty's State aid rules. ${ }^{43}$

Thus, the EC was of the opinion that the first prong of the three-prong test was satisfied. The EC then assessed whether there existed alternative purchasers. It noted that Treuhand had made extensive efforts to find purchasers for MdK, forty-eight firms were contacted and invited to submit tenders for the acquisition of MdK. Out of the forty-eight, nineteen had responded but the negotiations never reached the final stage. Based on this evidence, the EC was convinced that there existed no alternative purchaser for MdK.

\footnotetext{
${ }^{37}$ European Commission Guidelines on the assessment of horizontal mergers under the Council Regulation on the control of concentrations between undertakings, 2004 O.J. (C 31) 3, III89-91.

38 approximately $80 \%$ belonged to Kali und Salz and $20 \%$ to MdK.

${ }^{39}$ approximately $35 \%$ belonged to Kali und Salz and $25 \%$ to MdK.

${ }^{40}$ Approximately $80 \%$.

${ }^{41}$ Approximately $10 \%$.

${ }^{42}$ Case No. IV/M.308,Kali+Salz/MdK/Treuhan, 1993 O.J. (L 186) 38, II 3.

${ }^{43}$ Id. II 76.
} 
In addition to assessing the likelihood of MdK's withdrawal from the market and the (lack of) existence of alternative purchasers, the EC examined what would happen to the sales and market share of $\mathrm{MdK}$ if it exited the market. It was argued before the EC that even in the absence of the merger, the sales of MdK would have been taken over by Kali und Salz. The EC noted that this assertion was true for the German market because of structural reasons such as security of supply, product quality, and customer service. Thus, the most likely firm to capture the market share of MdK, even without the merger would be another German firm with a large market share, i.e., Kali und Salz. ${ }^{44}$ However, this was not the case for the market outside Germany which had fewer barriers to entry. ${ }^{45}$ Therefore, the deterioration of competition outside Germany was causally linked to the merger. ${ }^{46}$ Notably, the third prong of the test used by the EC was different from the one that has been adopted in the EU Merger Guidelines where parties need to show that the assets of the firm would exit the market in the absence of the merger. Under the EU Merger Guidelines, there is no need to show that the entire market share of the target firm would go to the acquiring firm in the absence of the merger. ${ }^{47}$

Despite the transaction not meeting the requirements of the third test, the EC approved the merger based on the first two tests. This was because of the economic weakness in regions of Eastern Germany. MdK's withdrawal from the market (which was established by the first test) would have the effect of destabilizing businesses. This would be detrimental to the objective of maintaining the Community's economic and social cohesion ${ }^{48}$ under the Merger Regulation. ${ }^{49}$ However, the relaxation of the third requirement in Kali und Salz was an exception, in subsequent cases, the EC applied all three tests strictly and rejected the failing firm defence when they were not met.

In Saint Gobain, ${ }^{50}$ the EC was evaluating a merger which would create a 60 per cent concentration in the silicon carbide market. The EC applied the three tests as enunciated in Kali und Salz but was not satisfied that they were fulfilled. ${ }^{51}$ The EC found that the target firm was not likely to exit the market (first test) and that there existed alternative purchasers whose acquisition of the target would cause lesser harm to competition (second test).52

\footnotetext{
${ }^{44}$ Id. II 78.

${ }^{45} I d$.

${ }^{46}$ Id. $\$ 179$.

${ }^{47}$ European Commission Guidelines on the assessment of horizontal mergers under the Council Regulation on the control of concentrations between undertakings, 2004 O.J. (C 31) 3, II 90.

${ }^{48}$ Case No. IV/M.308, Kali+Salz/MdK/Treuhan, 1993 O.J. (L 186) 38, II I95

${ }^{49}$ Council Regulation (EEC) 4064/89, 1989 O.J. (L 395) 1, recital 13.

${ }^{50}$ Case No. IV/M.744, Saint Gobain/Wacker-Chemie/NOM, 1997 O.J.(L 247) 1.

${ }^{51}$ KOKKORIS \& OLIVARES-CAMINAL, supra note 18 , at 119.

${ }^{52} \mathrm{Id}$.
} 
Importantly, the EC required that the entire share of the target should be consumed by the acquirer in the absence of the merger (third test), however, the parties were not able to prove this. The EC thus strictly applied the tests laid down in Kali und Salz to block the merger. ${ }^{53}$ In the Blokker/ Toys $R U_{S}^{54}$ merger the EC had another opportunity to decide on the failing firm defence. In this case, the first criterion was met, i.e., Toys R Us was likely to exit the market without the merger. However, the EC noted that all of Toys R Us' market share would not go to Blokker in the absence of the merger. Further, there existed alternative purchasers of Toys R Us that would lead to a less concentrated post-merger market. ${ }^{55}$ The EC mentioned that Toys R Us had chosen the strongest player (Blokker) to merge with, and that they had not explored other less anticompetitive options. Based on this reasoning, the EC did not approve the Blokker/ Toys $R$ Us merger.

A significant development in the application of the failing firm defence occurred in the $B A S F /$ Euridol/Pantochim ${ }^{56}$ case. This case involved the purchase of Euridol and Pantochim by BASF. Euridol and Pantochim were subsidiaries of the SISAS group, both these companies produced chemical products such as phthalic anhydride, gamma-butyrolactone (GBL) and tetrahydrofuran. BASF was involved in the distribution and production of chemical products, nutrition and health products, and gas and oil. ${ }^{57}$ The merger, inter alia, would have resulted in a concentration of 70 per cent in the GBL market, this clearly strengthened BASF's dominant position. Here, the EC applied the failing firm defence to approve the merger. The first two tests were kept the same as in Kali und Salz. The EC found that the firm was likely to withdraw from the market due to financial difficulties and that there was no alternative purchaser. For the third test, the EC noted that it was not feasible to apply it in cases where a duopoly did not exist. The EC held that it could not expect the BASF to absorb all the target's shares in the absence of a merger. ${ }^{58}$ But it found that in the absence of a merger, the assets of the targets would effectively exit the market. The EC noted that there were high costs associated with the operation of chemical plants including high environmental risks. ${ }^{59}$ In the absence of an alternative purchaser, not operating the target's plants would decrease the supply of their chemical products in the market, thus raising prices and harming

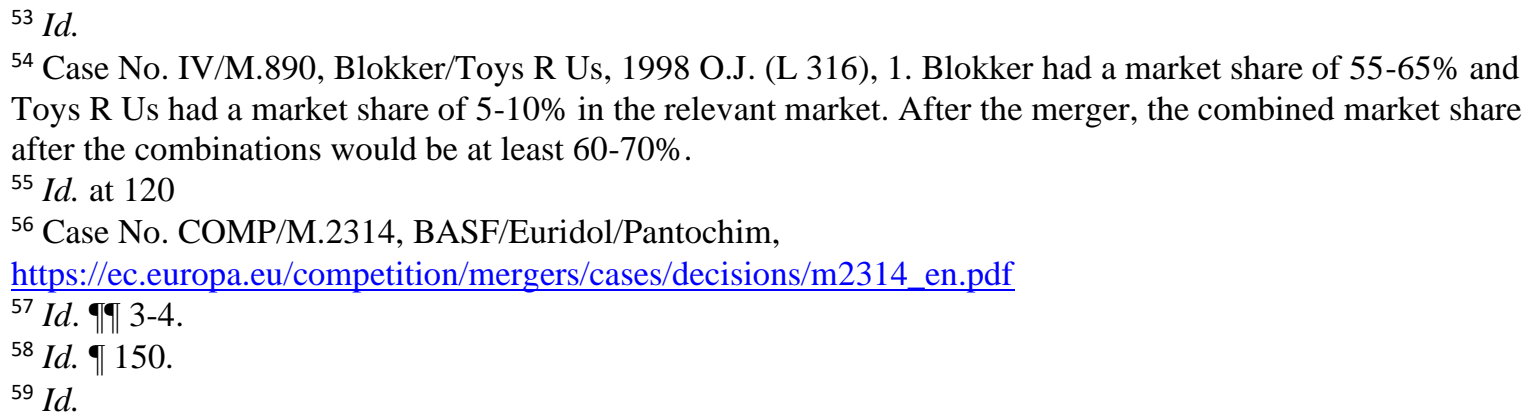


customers. ${ }^{60}$ The EC concluded that the detriment to competition would be worse in the absence of the merger and thus approved it. ${ }^{61}$ The decision in $B A S F$ relaxed the third test of failing firm defence, thus moving away from the position in Kali und Salz and later, in Saint Gobain. In $B A S F$, the third test required that the assets of the firm exit the market to the detriment of consumers and not that all of the target's market share be acquired in the absence of the merger. The new version of this test allows for a merger to be approved even if it shows that third parties may acquire some of the firm's market share in the absence of the concerned merger.

When assessing the likelihood of a firm's withdrawal from the market, there is no hard and fast rule for the EC to apply. Within the EU, each of the member states has a different insolvency procedure and different thresholds in place to determine when the insolvency process can be triggered and when a firm is declared bankrupt. ${ }^{62}$ For instance, France allows for the insolvency process to be triggered when a debtor is unable to pay their debts as they fall due, ${ }^{63}$ whereas Germany allows insolvency to be triggered when a firm has stopped paying it debts or when its assets no longer cover its existing obligations. ${ }^{64}$ This is why being subject to insolvency proceedings is not the sole criteria to determine whether a firm is likely to be forced out of the market in the near future. However, it can be strong evidence to demonstrate this along with other criteria such as unwillingness of the parent company to continue covering losses and the magnitude of losses made in the past. In $B A S F$, the EC noted that the targets and their parent company were undergoing pre-bankruptcy proceedings under Belgian law. No restructuring plan was proposed by the creditors of the targets and the Tribunal de commerce (which supervises the pre-bankruptcy proceedings) had stated that the targets would have to be declared bankrupt if no acquisition was approved. ${ }^{65}$

The EC did not refer to the objectives of insolvency law in order to make its decisions in the abovementioned cases. However, insolvency law was one of the factors used to assess the existence of alternative purchasers and the likelihood of a firm to exit the market, for instance, by being declared bankrupt.66 Overall, the assessment conducted when applying the failing firm defence is a competition assessment. Insolvency law was used as evidence to decide

\footnotetext{
${ }^{60} I d$. III $151-154$.

${ }^{61} \mathrm{Id}$.

${ }^{62}$ OECD Roundtable, supra note 23 , at 28,91 .

63 Joanna Gumpelson \& Philippe Dubois, France: Corporate Recovery and Insolvency, ICGL (May 15, 2019) https://iclg.com/practice-areas/corporate-recovery-and-insolvency-laws-and-regulations/france

${ }^{64}$ Insolvency Statute, Oct. 5, 1994, FEDERAL LAW GAZETTE at 2866 I, §§16, 19, https://www.gesetze-iminternet.de/englisch_inso/englisch_inso.html\#p0071.

${ }^{65}$ Case No. COMP/M.2314, BASF/Euridol/Pantochim, https://ec.europa.eu/competition/mergers/cases/decisions/m2314_en.pdf, II 144 ${ }^{66} I d$.
} 
whether the conditions required to successfully establish the failing firm defence existed, but the objectives of insolvency law were not used to decide whether the merger should be allowed. The interests of consumers and the market take precedence in the EC's decision making. This was most clearly seen in Toys $R U_{s} / B l o k k e r$ where the EC blocked a merger despite the fact that a firm was likely to fail in its absence. 67 The EC noted that there existed less anticompetitive acquirers, and that the Toys R Us had deliberately chosen a large, more established acquirer i.e., Blokker.

\subsection{Failing division defence}

The failing division defence is an extension of the premise of the failing firm defence. The difference being that the failing division defence is applied to a branch or division of a firm rather than the entire firm. ${ }^{68}$ The burden of proof is higher when establishing a failing division defence because it is possible for a group of companies to creatively use accounting techniques to make it seem like one of their divisions is failing. ${ }^{69}$ If not applied strictly by competition authorities, the failing division defence can become a means by which a group can get rid of an unprofitable business while escaping competition scrutiny. ${ }^{70}$ In Aerospatiale the EC considered the acquisition of Boeing's division in Canada (De Havilland) by a corporation called Alenia and Aerospatiale. ${ }^{71}$ The merger would have resulted in a combined worldwide market share of 64 per cent in the market for medium sized turboprop aircrafts which clearly increased the concentration within the market. ${ }^{72}$ The parties argued that without the merger, De Havilland would be forced to exit the market as Boeing was going to phase out the production of its medium sized turboprop aircrafts. The EC was not convinced that this was likely, given that De Havilland produced good quality aircrafts whose prices were rising. ${ }^{73}$ The EC went on to state that even if Boeing wanted to sell De Havilland, there were other purchasers to whom it could sell (other than Aerospatiale and Alenia) thus preventing its exit from the market. ${ }^{74}$ The failing division defence has been unsuccessfully used by parties in

\footnotetext{
${ }^{67}$ KOKKORIS \& OLIVARES-CAMINAL, supra note 18 , at 120

${ }^{68}$ OECD Roundtable, supra note 23, at 186.

${ }^{69}$ Id. See KOKKORIS \& OLIVARES-CAMINAL, supra note 18 , at 114-115.

${ }^{70}$ OECD Roundtable, supra note 23, at 186.

${ }^{71}$ Case IV/M.053, Aerospatiale-Alenia/De Havilland 1991O.J. (L 334) 42, II 1.

${ }^{72} I d$. at II 26. See KOKKORIS \& OLIVARES-CAMINAL, supra note 18, at 114.

${ }^{73}$ Case IV/M.053, Aerospatiale-Alenia/De Havilland 1991O.J. (L 334) 42, II 31.

${ }^{74} \mathrm{Id}$.
} 
Bertelmann/Kirch/Premiere, ${ }^{75}$ Rewe/Meinl, ${ }^{76}$ and NewsCorp/Telepiu. ${ }^{77}$ The EC is yet to accept the failing division defence as the basis for approving an otherwise anticompetitive merger, this stands in stark contrast to the success of the failing firm defence. ${ }^{78}$

\section{Merger Control in India}

India's competition regime is contained in the Competition Act (the Act). The Act regulates various types of anticompetitive behaviour including anticompetitive agreements (Section 3), abuse of dominance (Section 4) and combinations (Sections $5 \& 6$ ). The CCI is empowered to investigate and pass orders under the Act. The CCI draws it power to scrutinise mergers from sections $5 \& 6$ of the Act.

Section 5 defines combinations as transactions (mergers and acquisitions) which meet certain thresholds. These thresholds are revised from time to time. Currently, when the combined assets of the parties exceed INR 20 billion in India or USD 1 billion worldwide with at least INR 10 billion of these assets in India, the transaction is a combination, and needs to be notified before it is implemented. A merger or acquisition will be a combination if the combined Indian or world-wide turnover of the parties is over INR 60 billion or USD 3 billion (with at least INR 30 billion of this in India) respectively. An acquisition or merger will also be a combination if it results in a party joining a group whose assets or turnover after the transaction in India is INR 80 billion or USD 240 billion respectively, or if the group's worldwide assets or turnover after the merger is USD 4 billion with at least INR 10 billion in India, or USD 12 billion with at least INR 30 billion in India respectively.

Section 6 prohibits combinations which cause an appreciable adverse effect on competition or AAEC and declares these to be void. ${ }^{79}$ The section also requires that all combinations be notified to the CCI before they are implemented. 80 Thus, if a proposal to enter into a combination has been approved by the Board of Directors of a company or if an agreement to transfer control has been executed, the same needs to be notified within 30 days. ${ }^{81}$

\footnotetext{
${ }^{75}$ Case IV/M.993, Bertelmann/Kirch/Premiere, https://ec.europa.eu/competition/mergers/cases/decisions/m993_19980527_610_en.pdf (1998)

${ }^{76}$ Case IV/M.1221, Rewe/Meinl, https://ec.europa.eu/competition/mergers/cases/decisions/m1221_19990203_600_en.pdf (1999).

${ }_{77}$ Case COMP/M.2876 NewsCorp/Telepiu, https://ec.europa.eu/competition/mergers/cases/decisions/m2876_en.pdf (2003).

${ }^{78}$ OECD Roundtable, supra note 23, at. 186.

${ }^{79}$ Competition Act, supra note $2, \S 6(1)$

${ }^{80}$ Id. $\$ 6(2)$

${ }^{81} \mathrm{Id}$.
} 
The CCI has the power to investigate combinations under Section 20 of the Act and can pass orders under Section 31. After its investigation, the CCI can either approve the combination, prohibit it, or approve the combination subject to modifications. The 2019 Combination Regulation Amendment has inserted Regulation 5A which allows for green-channelling combinations where there is no vertical or horizontal overlap between the parties and no overlap in the production of complementary products. As already mentioned, a greenchannelled combination will be declared as void ab-initio if it is found that the information submitted is incorrect or that there exist any horizontal or vertical overlaps in the proposed combination. ${ }^{82}$

In order to determine whether a combination causes AAEC, the CCI considers various factors. Any determination in this regard is bound to vary on a case by case basis. The factors considered by the CCI include, existing and potential level of competition in the market (including imports), extent of barriers to entry, current level of market concentration, market share of the parties in the combination, existence of substitutes and the level of countervailing power in the market, level of innovation in the market, and advantages of the combination and whether they outweigh its anticompetitive effects. The possibility of a failing business has also been mentioned as one of the factors which the CCI may consider. ${ }^{83}$ However, the failing firm defence, till date, has been used only once by the CCI when scrutinising IRPs (See Section 7 on IRPs assessed by the CCI).

As green-channelling prevents the CCI from scrutinising mergers before their implementation, it is similar to the voluntary regime currently in place in the UK where mergers do not need to be notified before their implementation. Given that the 2019 Combination Regulation Amendment leans towards this direction, it is worth understanding how the UK's merger regime works.

\section{The UK's Competition and Markets Authority - A voluntary merger regime}

The UK's experience will have increased relevance in India if it moves towards a voluntary notification regime by allowing some mergers to be green-channelled. In the UK, enterprises are not required to notify the Competition and Markets Authority (CMA) prior to completing a combination transaction which could have detrimental effects to competition. ${ }^{84}$ The UK does

\footnotetext{
82 The Competition Commission of India (Procedure in regard to the transaction of business relating to combinations) Amendment Regulations, 2019, Regulation 2.

${ }^{83}$ Competition Act, supra note 2, § 20(4)(k).

${ }^{84}$ COMPETITION AND MARKETS AUTHORITY, MERGERS: GUIDANCE ON THE CMA's JURISDICTION AND PROCEDURE (2014), 11-16, 42,
} 
not have a suspensory regime and pre-merger notifications by merging enterprises are purely voluntary. 85

The CMA, the UK's competition regulator, was established under Part 3 of the Enterprise and Regulatory Reform Act, 2013. The CMA replaced the Competition Commission and Office of Fair Trading, thus subsuming their powers and functions. The substantive law regulating merges is contained in the Enterprise Act, 2002;86 the Enterprise and Regulatory Reform Act amended the Enterprise Act to make the CMA the UK's competition regulator. ${ }^{87}$ There are two phases to the CMA's merger scrutiny, both of which rely on the existence of a 'relevant merger situation'. 88

The Enterprise Act prescribes three criteria which need to be fulfilled for the existence of a relevant merger situation. Firstly, there must be a transaction where two or more enterprises 'cease to be distinct' or such a transaction must be contemplated. ${ }^{89}$ Enterprises cease to be distinct when they are owned or controlled by the same entity. Secondly, the turnover of the target must be over GBP 70 million or the merging enterprises must be buyers or sellers of at least 25 per cent of the goods or services in their industry within the UK. ${ }^{90}$ Thirdly, the merger must either not have been completed or must not be older than four months. In case the merger was not made public, the time limit mentioned in the third criteria is calculated from the date on which the merger was made public or the CMA was informed of it. ${ }^{91}$

In Phase 1 of its investigations, the CMA decides whether it has the duty to refer a transaction to Phase 2 investigations. During Phase 1, the CMA assesses whether there exists or there is likely to exist a relevant merger situation and whether this situation could lessen competition. If the CMA finds that both these conditions are met, it has a duty to refer the transaction for more detailed Phase 2 investigations. There are some factors which can mitigate the CMA's duty to refer a merger. If the market in which the relevant merger situation and lessening of competition occur is not important enough or if the customer benefits from the transaction are greater than the harms it causes by lessening competition, the CMA may refrain from

https://assets.publishing.service.gov.uk/government/uploads/system/uploads/attachment_data/file/384055/CMA 2_Mergers_Guidance.pdf.

$85 \mathrm{Id}$.

${ }^{86}$ Enterprise Act 2002, c. 40, Part 3 (United Kingdom)

${ }^{87}$ Enterprise Regulatory and Reform Act 2013, c. 24, § 29.

${ }^{88}$ COMPETITION AND MARKETS AUTHORITY, MERGERS: GUIDANCE ON THE CMA'S JURISDICTION AND PROCEDURE (2014), 6

89 §23(2) Enterprise Act

90 \$23(3) Enterprise Act

${ }^{91} \S 24(1)$ 
referring the transaction. ${ }^{92}$ If there is uncertainty about whether a merger is likely to create a relevant merger situation and lessen competition, the CMA applies a rule of caution and refers the merger for further investigation. ${ }^{93}$

Phase 2 investigations are conducted by an Inquiry Committee set up by the CMA for this purpose. Phase 2 investigations comprise a detailed assessment of the merger and its effects on the market. Three main questions characterise Phase 2 , the first is whether there exists a relevant merger situation. Phase 1 investigations also form an opinion on whether there exists or is likely to exist a relevant merger situation, however this is only a prima facie opinion and does not bind Phase 2 investigations. Phase 2 investigations conclusively determine the question of whether a relevant merger situation exists. The second question is whether the relevant merger situation substantially lessens competition. If the answers to the first two questions are in the affirmative, then the merger is anticompetitive. Thereafter, the CMA must decide on the third question on whether it should take any action to remedy or mitigate the anticompetitive effect and the nature of this remedial action.

The Enterprise Act does not define what amounts to a 'substantial lessening of competition' (SLC). However, the standards to assess SLC have been provided in the UK Merger Assessment Guidelines. ${ }^{94}$ SLC refers to the reduction in the rivalry between firms. A reduction in rivalry might mean that firms reduce the competitiveness of their prices, the quality of their products, or stop non-price competition (such as the provision of additional services/information along with the product). Lesser rivalry in more highly concentrated markets could have the effect of reducing a firm's incentive to innovate and compete, thus being detrimental to customers. ${ }^{95}$ The ways in which mergers can harm competition are described through the 'theories of harm'. ${ }^{96}$ The theories of harm provide a framework through which the SLC of a merger is assessed. ${ }^{97}$ These theories conceptualise the effects that mergers can have on a market such as the ability to raise prices or reduce prices as a result of increased market power (unilateral effects), the ability to coordinate competitive behaviour and assert

\footnotetext{
92 COMPETITION ANd MARKETS Authority, MERgERs: GUIDANCE ON THE CMA's JURISDICTION AND PROCEDURE (2014), I[ 3.2 .

${ }^{93} I d$. at 1 I 3.7

${ }^{94}$ COMPETITION COMmission \& OfFice OF FAIR Trading, MERGER Assessment Guidelines (September 2010), 19-20, https://assets.publishing.service.gov.uk/government/uploads/system/uploads/attachment_data/file/284449/OFT1 254.pdf; See Akzo Nobel NV v. Competition Commission \& Ors. (2014) Bus. LR 802.

${ }^{95}$ COMPETITION COMMission \& OfFICE OF FAIR TrAding, MERGER Assessment Guidelines (September 2010), 10, https://assets.publishing.service.gov.uk/government/uploads/system/uploads/attachment_data/file/284449/OFT1 254.pdf [Henceforth UK Merger Assessment Guidelines]

${ }^{96}$ WHISH \& BAILEY, supra note 25 , at 892

${ }^{97}$ UK Merger Assessment Guidelines, supra note 95, at 20.
} 
'collective dominance' (coordinated effects), and the ability to foreclose upstream or downstream businesses in vertical mergers.

The CMA in the UK uses a counterfactual test as an analytical tool to assess the SLC of a merger. The CMA looks at foreseeable developments in the market with the merger and without it, these include, the likelihood of new entrants, the ability of competitors to increase production etc. Normally a counterfactual describes the prevailing conditions in the market (before the merger). The failing firm defence differs from other counterfactuals as it describes a situation which is different from prevailing conditions. The failing firm defence requires that the competition authorities compare the post-merger situation with a situation in which one of the firms exits the market and not with the situation prevailing in the market (in which both firms are present and competing).

\section{Competition scrutiny of IRPs in India}

After the IBC's provisions relating to corporate insolvency took effect in August 2016, the CCI has been notified of sixteen IRPs which contained combinations (See Annexure I for details). This section discusses the CCI's approach to assessing IRPs and potential areas of conflict between insolvency law and competition law in the context of IRPs.

\subsection{Taxonomy of IRPs assessed by the CCI}

Nine out of the sixteen IRP combinations scrutinised by the CCI concerned the steel industry, and eight of them had some horizontal overlaps. The post-merger combinations of parties ranged from 5-10 per cent to 35-40 per cent across various steel products. All orders discussed the countervailing forces present in the market in the form of other firms. Notably the CCI orders focused on unilateral effects of market concentration and not potential coordinated effects. The CCI has held that the Competition Act does not recognise collective dominance. 98 However, it does recognise cartelisation and prohibit it, ${ }^{99}$ which is also a coordinated effect. Thus, the fact that the Competition Act does not recognise collective dominance cannot be the sole reason for not considering the potential coordinated effects (such as raising prices) of a combination. The existence of a few large steel producers can increase the likelihood of coordinated behaviour just as it can increase their incentive to maintain the level of competition in the market (countervailing factors). This is not to say that the IRP

\footnotetext{
${ }^{98}$ Ashok Kumar Vallbhaneni v. Geetha SP Entertainment and Ors. (2019) SCC OnLine CCI 27, II 13.

${ }^{99}$ Competition Act, supra note $2, \S 3$.
} 
combinations have resulted in coordinated effects, however, an analysis of coordinated effects would be warranted in a rapidly consolidating industry. ${ }^{100}$

The remaining IRPs related to agri-business, cement, wind energy, construction, and telecommunications. In the merger relating to telecommunications, two cellular service providers undergoing the insolvency process were acquired by an asset reconstruction company, there was thus no horizontal or vertical overlap. ${ }^{101}$ The rest of the mergers had some horizontal or vertical overlaps but the market shares of the parties were insignificant, thus resulting in no AAEC.

In order to understand whether IRP combinations were assessed differently, we have compared them to regular combinations, the nine IRP combinations in the steel sector were compared to regular combinations in the sector. IRP combinations in the steel sector were chosen because they comprise the majority of IRPs assessed by the CCI, making it easy to find patterns in the assessments. There was no difference between how the CCI approached IRP combinations and regular combinations (Annexure I). To demonstrate the similarity in the CCI's approach, we compare two combination orders (an IRP combination and a regular combination) of the CCI.

The IRP combination between ArcelorMittal and Essar Steel India ${ }^{102}$ and the regular combination between Nippon \& Steel Sumitomo Metal Corporation and Sanyo Co. Ltd were both approved by the CCI in 2018. ${ }^{103}$ These two combinations are a good place to begin comparing the CCI's approaches as the combined market shares of parties in both these combinations after the merger were similar (around 20 per cent). Interestingly, Essar Steel was acquired jointly by ArcelorMittal and Nippon Steel through the former's holding company. In both combination orders, the CCI first assessed the particulars of the transaction between the parties i.e., how the acquisition was structured. After discussing the transaction, the CCI orders looked at the businesses in which the parties were engaged. In both combinations the parties were engaged in the manufacturing and sale of steel products.

Once the background of the parties and the nature of the transaction were examined, the CCI studied the relevant product markets for potential overlaps. In both combinations, the CCI reiterated that there are different production processes and inputs used in the steel industry.

\footnotetext{
${ }^{100}$ IBC process to push consolidation in steel industry, says EY, ECON. TIMES (Jun. 21, 2018), https://economictimes.indiatimes.com/industry/indl-goods/svs/steel/ibc-process-to-push-consolidation-in-steelindustry-says-ey/articleshow/64683924.cms?from $=$ mdr.

101 Combination Registration No. C-2019/02/642 (Mar. 7, 2019).

102 Combination Registration No. C-2018/08/593 (Sep. 18, 2018) (henceforth ArcelorMittal Order)

${ }^{103}$ Combination Registration No. C-2018/09/597 (Nov. 30, 2018) (henceforth Nippon Steel Order)
} 
Accordingly, the CCI noted that steel products form different relevant product markets based on their characteristics, intended use, price etc. Once the relevant product markets are identified the CCI looks for overlaps in the product markets of the parties to the combination.

In Nippon Steel, the CCI found a horizontal overlap between the parties in the markets for specialty steel bars, seamless pipes, and rings. The combined market share of the parties in the Nippon Steel combination was assessed to be 15-20 per cent (specialty steel bars) and 0-5 per cent (seamless pipes). For the CCI, neither of these concentrations were high enough to cause an adverse effect on competition. ${ }^{104}$ In the ArcelorMittal combination, the parties' businesses overlapped in the domestic sales of tubes and pipes. However, the combined market share of both parties was lesser than 20 per cent and thus did not raise any competition concerns. ${ }^{105}$ In the Nippon Steel combination order, it was noted that there were other competitors in the market that would serve as constraints on the parties' behaviour in the market. 106

All other orders of the CCI followed a similar pattern for assessing IRP combinations. The CCI first assessed the businesses in which the partiers were involved and whether there were any horizontal or vertical overlaps between them. The CCI then looked at the market shares of each party before and after the merger and (sometimes) took note of the incremental change in market share for each relevant market. Finally, it would look at the existence of countervailing factors in the form of competitors. In some cases, the CCI took note of the capacities at which other firms in the market were operating, if they were not operating at full capacity, this meant that they could increase their production if the demand for substitutes increased (due a rise in the prices of the merged party). ${ }^{107}$

The only difference between IRP combinations and regular mergers was that in a few of the latter, the CCI used the Herfindahl-Hirschman Index (HHI) test to gauge the concentration of a market and whether the change in market concentration was significant. This was done for regular mergers in the cement industry. The HHI levels can be used to compare the level of market concentration before and after a merger. The difference between the two concentrations is known as the 'delta', which is an important indicator of whether an increase in market concentration is significant. The HHI was not used in the IRP combinations nor were other tests such as Elzinga-Hogarty (for determining the relevant geographical market,

\footnotetext{
${ }^{104}$ Supra Nippon Steel Order, III 10-11.

105 Supra ArcelorMittal Order, II 11.

${ }^{106}$ Supra Nippon Steel Order, III 10-11.

107 See Combination Registration No. C-2018/03/562 (Apr 4, 2018); Combination Registration No. C2018/03/561 (May 11, 2018).
} 
also used in non-IRP cement cases). The CCI has held that HHI index levels below 1000 indicate that the market is not concentrated, levels between 1000 and 2000 mean that the market is moderately concentrated, and levels above 2000 mean that the market is highly concentrated. ${ }^{108}$ The CCI has also held that mergers that would raise concerns about adverse effects on competition are those where either the difference in pre-merger and post-merger HHI level is 150 or more (in a highly concentrated post-merger market) or 250 or more (in a moderately concentrated post-merger market). ${ }^{109}$

Interestingly, the CCI referred to the failing firm defence in only one of the IRP combinations, ${ }^{110}$ but without any detailed explanation. The CCI only referred to the imminent failure of the firm (which is the first test in the failing firm defence) and how this would be a detriment to end users. The reason for such a brief reference to the failing firm defence may be that no AAEC was attributable to the merger. The failing firm defence is used to persuade competition authorities to approve mergers which lead to some deterioration in competition, if no significant deterioration is found, competition authorities would not need to employ the defence to approve the merger. None of the IRP combinations were found to cause AAEC. The existence of 'possibility of a failing business' in the Competition Act as a factor that can be considered by the CCI when assessing the merger shows that the failing firm defence falls within the scope of the Competition Act. ${ }^{111}$ However, there is a dearth of Indian case laws on how the failing firm defence is to be applied, this is exacerbated by the lack of Indian merger guidance on the subject.

The CCI does not have any readily available guidance on merger control per se. It has a Competition Advocacy Booklet (which is not binding) on the subject that explains the law relating to combinations and how it will be applied. ${ }^{112}$ However, the Advocacy Booklet is not very detailed, for this reason, the contours of the application of the failing firm defence in India remain unclear. The UK and the EU each have a separate section of their merger control guidance dedicated to the failing firm defence and its application. This is the practice in Canada and the US as well. ${ }^{113}$ Further, the merger guidelines of these countries use case laws to explain how the provisions in the legislation will be applied by competition authorities.

\footnotetext{
108 Combination Registration No. C-2015/07/288 (May 4, 2016).

109 Id. II 43.

${ }^{110}$ Combination Registration No. C-2019/03/650 (Apr. 9, 2019)

${ }^{111}$ Competition Act, supra note 2, § 20(4)(k).

${ }^{112}$ Competition Commission of India, Provisions relating to Combinations (Advocacy Series 5), https://www.cci.gov.in/sites/default/files/advocacy booklet_document/combination.pdf.

${ }^{113}$ COMPETITION Bureau (CANADA), MERGER ENFORCEMENT Guidelines, Part 13, https://www.competitionbureau.gc.ca/eic/site/cb-bc.nsf/eng/03420.html; DEPARTMENT OF JUSTICE AND FEDERAL TRAdE COMMISSION (United STATES), Horizontal Merger Guidelines, 32, https://www.ftc.gov/sites/default/files/attachments/merger-review/100819hmg.pdf.
} 
There exist other mechanisms by which firms can pre-emptively take steps to make their merger competition compliant, for instance, seeking expert counsel or entering into consultations with the CCI. ${ }^{114}$ However, having detailed merger guidance is a practice adopted by jurisdictions with well-developed competition laws and India would be following international best practices if it updated its Competition Advocacy Booklets. Detailed guidelines will also help creditors participating in the insolvency resolution process make informed decisions about the plans they vote on and ultimately approve. Creditors, through the Committee of Creditors $(\mathrm{CoC})$, are at the helm of the insolvency resolution process. ${ }^{115}$ When the CCI scrutinises the competition effects of an IRP, it is essentially assessing the competition effects of the CoC's decision.

\subsection{Limitations of 'creditors' wisdom' in the insolvency resolution process}

The IBC assigns the authority to decide whether to rehabilitate a corporation undergoing the insolvency resolution process to the $\mathrm{CoC}$ on account of the commercial wisdom held by it.116 Since the CCI has approved all the IRPs it has been notified of thus far, it has never had to render a decision that would go against the decision of the CoC. In two sets of orders, the CCI scrutinised (and approved) more than one IRP for a corporate debtor These cases are important as they highlight the priorities on the $\mathrm{CoC}$ during the insolvency resolution process. The first set of cases concerned two separate bids for the acquisition of Binani cements which would have resulted in horizontal mergers. The first bid proposed the acquisition of Binani Cements (which was undergoing the insolvency process) by a subsidiary of Dalmia cements. ${ }^{117}$ This was rejected for being discriminatory by the National Company Law Tribunal (NCLT) and the National Company Law Appellate Tribunal (NCLAT). The plan proposed by Dalmia's subsidy paid similarly placed financial creditors different proportions of the debt due to them. ${ }^{118}$ However, the plan raised no concerns on the competition front as the combined market share of both parties was only 0-5 per cent. After Dalmia's plan had not been approved by the NCLAT, Binani's CoC voted in favour of Ultratech cement's plan for the acquisition of Binani Cements. Ultratech nearly doubled Dalmia's offer to acquire Binani. This was the second IRP combination concerning Binani Cements scrutinised by the CCI and it was also

\footnotetext{
${ }^{114}$ Competition Commission, Consultation prior to filing of notice of the proposed combination under subsection (2) of section 6 of the Competition Act, https://www.cci.gov.in/sites/default/files/cci_pdf/PFCguidancenote.pdf.

${ }^{115} \mathrm{IBC}$, supra note $12, \S 30$.

${ }^{116}$ Id. See MinisTRY OF CORPORATE AFFAIRS, REPORT OF THE INSOLVENCY LAW COMMITTEE (March 2018), http://www.mca.gov.in/Ministry/pdf/ReportInsolvencyLawCommittee_12042019.pdf)

${ }^{117}$ Combination Registration No. C-2018/02/557 (Mar. 7, 2018)

118 Combination Registration No. C-2018/02/558 (Mar. 27, 2018) \& Binani Industries v. Bank of Baroda \& Ors., Company Appeal No. 81/2018 (NCLAT), https://nclat.nic.in/Useradmin/upload/3893249755bebcea7be390.pdf
} 
approved. 119 The CCI noted that the combined market share of Ultratech Cements and Binani cements was between 20-25 per cent and that there were other competitors in the market to restrain the parties from engaging in any anticompetitive behaviour. ${ }^{120}$

Similar circumstances arose in the case of JSW Steel's acquisition of Bhushan Power and Steel Ltd. (BPSL), which was undergoing an insolvency resolution process. Tata Steel Ltd and JSW Steel both submitted their bids to acquire BPSL to BPSL's CoC. ${ }^{121}$ Initially, Tata Steel had the highest bid, however, the $\mathrm{CoC}$ allowed for the submission of revised bids, of which JSW had the highest offer. The CoC voted on JSW Steel's offer and accepted it. This acquisition was unsuccessfully challenged before the NCLAT by Tata Steel on the grounds that JSW were unfairly favoured by the $\mathrm{CoC}$ when they allowed JSW Steel to revise its bid multiple times. Following the precedent set in the Binani cements case, the NCLAT held that the CoC had a duty to maximise the assets of the corporate debtor and was allowed to consider improved financial offers from bidders. ${ }^{122}$

The two sets of cases in the cement and steel industry discussed above are significant. In both instances, the NCLAT encouraged the $\mathrm{CoC}$ to consider the offer of the highest bidder. It may be recalled that in the Blokker/ Toys $R U_{S}$ and Saint Gobain mergers in the EU, one of the problems was that the acquirer was already a large entity in the market. Thus, competition was likely to reduce after the merger because of an increase in market concentration. In Blokker/Toys $R U_{S}$ and Saint Gobain, the second test of the failing firm defence was not met and it was found that less anticompetitive (smaller) acquirers would be more compatible with the EU's merger control regime. The Binani and BPSL cases decided by the NCLAT show that creditors (who vote on IRPs) favour larger acquirers which are more likely to be antithetical to competition. These cases reveal the tensions between the interests of the $\mathrm{CoC}$ and those of competition law.

Undoubtedly, competition scrutiny of IRPs can come in the way of creditors' ability to negotiate the best deal for themselves. Larger firms will be able to offer more money to repay the debts of financial and operational creditors, ${ }^{123}$ however, combinations with larger firms having horizontal overlaps are also more likely to create a dominant entity in the market. Creditors are subject to the constraints of other laws in status quo as well and the NCLT is

\footnotetext{
119 Combination Registration No. C-2018/02/558 (Mar. 27, 2018)

${ }^{120} \mathrm{Id}$.

${ }^{121}$ Tata Steel Ltd. v. Liberty House \& Ors. (2019) SCC OnLine NCLAT 13, II 5.

${ }^{122}$ Id. II $\llbracket[33-36$.

${ }^{123}$ See Combination Registration No. C-2018/02/558 (Mar. 27, 2018) \& Binani Industries v. Bank of Baroda \& Ors., Company Appeal No. 81/2018 (NCLAT), https://nclat.nic.in/Useradmin/upload/3893249755bebcea7be390.pdf
} 
bound to only approve those IRPs which do not violate existing laws in force. ${ }^{124}$ Further, it is one of the duties of the insolvency resolution professional to ensure that the IRP does not contravene any law in force. ${ }^{125}$ Competition law is one such law and the interests of the CoC will have to be balanced with those of the market.

\subsection{The NCLAT: an institutional bridge between merger control and insolvency law}

The NCLT supervises the insolvency resolution process under the IBC. Appeals from the NCLT lie with the National Company Law Appellate Tribunal or the NCLAT. In 2019, the NCLAT replaced the Competition Appellate Tribunal (COMPAT) and was put in charge of hearing appeals from the CCI. The unification of the functions of the COMPAT with those of the NCLAT provides a unique opportunity to cater to the objectives of competition law and insolvency law. If IRPs meeting merger thresholds were put under the original jurisdiction of the NCLAT, they would be reviewed by expertise and inputs from insolvency and competition specialists. The NCLT already has to ensure that the IRP does not violate any laws in force. ${ }^{126}$ As an extension this provision, the NCLAT can be allowed to check if an IRP that meets combination thresholds has created any AAEC; this can be an alternative to implementing the proposal in the Report where IRPs would be approved without even probing into the question. The text of the IBC facilitates coordination between the CCI and insolvency regime before and IRP is implemented. The IBC requires an applicant to ensure that IRP combinations are approved by the CCI before they are presented to the CoC. The NCLAT has held that this provision in the IBC is a directory one and not mandatory, meaning that the CoC can approve a plan pending the CCI's scrutiny. Nevertheless, the NCLT can encourage applicants proposing IRPs to get them approved by the CCI prior to being voted on by the CoC.

Green-channelling exempts IRPs from merger scrutiny, however, it does not stop persons from filing complaints under Section 4 of the Competition Act (abuse of dominant position). Merger scrutiny prior to the implementation of an IRP will not stop complaints under Section 4 from being filed, but it will prevent mergers that lead to highly concentrated markets, thus ensuring that the merged entity does not have a dominant position in the first place. The $\mathrm{CoC}$ of the corporate debtor can invite other less anticompetitive bids based on the decision of the CCI. The entire process requires a careful balance to be struck between the decisional

\footnotetext{
${ }^{124} \mathrm{IBC}$, supra note $12, \S \S 30(2), 31$.

${ }^{125} I d$. $\S 30(2)(\mathrm{e})$.

${ }^{126} I d . \S \S 30(2), 31$.
} 
autonomy of the $\mathrm{CoC}$ under the IBC and the objectives of merger control under the Competition Act. After subsuming the role of the COMPAT, the NCLAT is well placed to balance these interests.

\section{Merger control: its relevance in competition regimes and effects on insolvency} regimes.

The role of merger control in the Indian competition regime, specifically, the desirability of a pre-merger notification regime was debated in the Raghavan Committee Report, ${ }^{127} 1999$ (which formed the basis for the Competition Act, 2002 and was reiterated in the 2019 Competition Law Report). ${ }^{128}$ The Raghavan Committee report considered whether India needed a merger control regime to maintain competition in the market. ${ }^{129}$ It noted that if firms were entering into anticompetitive agreements (such as price fixing, market sharing, or tie-in agreements) or abusing their dominant position, the competition regulators could impose penalties and take remedial measures (such as breaking up a dominant firm). ${ }^{130}$ The harms that are likely to arise from increased market concentration would fall within the categories of abuse of dominance or anticompetitive agreements. ${ }^{131}$ The committee also noted that despite the overlap between the anticompetitive effects of high market concentration and abuse of dominance, most countries had merger control regimes. This was because merger control allowed competition authorities to pre-emptively address consolidation that would have a detrimental effect on competition. The goal of merger regulation is not restricted to preventing an abuse of dominance but to encourage competition between firms and maintain a level of rivalry and competition. ${ }^{132}$ This may be the reason for why there has been a proliferation of merger control regimes across over 100 jurisdictions. ${ }^{133}$ Suspensory merger regimes in particular have the ability to screen mergers which may be harmful to consumers and modify or prohibit them before they are implemented. For instance, the Federal Trade Commission in the US has found that its merger control led to significant savings for

\footnotetext{
${ }^{127}$ Government of India, Report of the High Level Committee on Competition Policy and Law (May 2000), https://theindiancompetitionlaw.files.wordpress.com/2013/02/report_of_high_level_committee_on_competition _policy_law_svs_raghavan_committee.pdf. [Henceforth Raghavan Committee Report].

${ }_{128}$ MinistRy OF CORPORATE AFFAIRS, REPORT OF THE COMPETITION LAW REVIEW COMMITTEE (July 2019), II

4.2, http://www.mca.gov.in/Ministry/pdf/ReportCLRC_14082019.pdf.

${ }^{128}$ Competition Act, supra note 2, §5.

${ }^{129}$ Raghavan Committee Report, supra note 127, II 4.7.8.

${ }^{130} \mathrm{Id}$.

${ }^{131} \mathrm{Id}$.

${ }^{132}$ WHISH \& BAILEY, supra note 25 , at 817.

${ }^{133} \mathrm{Id} .812$
} 
consumers. ${ }^{134}$ The Hart - Scot-Rodino Act established the pre-merger notification regime in the US ${ }^{135}$ and the Federal Trade Commission submits annual reports on the working of this regime to Congress. The 2018 annual report reiterated that the pre-merger notification regime protected the interests of consumers. ${ }^{136}$

\subsection{Suitability of voluntary merger regimes to IRPs.}

The costs attributed to enforcing anticompetitive remedies on existing entities is significant in the context of insolvency law. Under the Competition Act, the CCI has the power to divide entities which have a dominant position to ensure that there is no abuse. ${ }^{137}$ The process by which an IRP is approved is a sensitive one. It involves creditors forgoing parts of their loans, extending additional credit, or postponing the dates on which their loans are due. ${ }^{138}$ Further, IRPs are also important for the customers of the financially distressed company, they signal the scale at which the company will continue to operate. In a pre-merger notification regime, an IRP cannot be implemented until it is cleared by the CCI. This allows new proposals to be voted on by the $\mathrm{CoC}$ in case the CCI rejects or modifies an earlier proposal. However, in a situation where merger control happens after the combination is implemented, the creditors do not have the ability to look at other proposals and renegotiate the plan. Once the merger is implemented, merger control requires detangling of assets; generally, unwinding mergers (including IRPs) after their implementation increases legal uncertainty. ${ }^{139}$ When the predictability associated with the insolvency resolution process reduces, creditors might be less likely to commit more money to a restructuring plan as they would not know whether the company will be able to function as per the IRP. The Combination Regulation Amendment is significant in this regard. Under Regulation 5A of the Combination Regulations, a merger found to be non-compliant with green-channel requirements will be void ab-initio. This is different from Section 6 of the Competition Act which says that combinations which are not notified will be void. When a transaction is void ab-initio, it is treated as though it never occurred. This increases the risks associated with investing in distressed assets subject to

\footnotetext{
${ }^{134}$ Phillip Nelson \& Su Sun, Consumer savings from merger enforcement: a review of the antitrust agencies' estimates, 69 ANTITRUST L. J. (2002), 921.

${ }^{135}$ Hart-Scot-Rodino Antitrust improvements Act, 15 U.S.C. §18a,(2020). See Clayton Act, 15 U.S.C. § 7A (2020).

${ }^{136}$ Federal Trade Commission Department of Justice (US), Hart-Scot-Rodino AnNuAl RePort (FY

2018), https://www.ftc.gov/system/files/documents/reports/federal-trade-commission-bureau-competitiondepartment-justice-antitrust-division-hart-scott-rodino/fy18hsrreport.pdf, pp. 3, 18.

${ }^{137}$ Competition Act, supra note 2, $\S 28$.

${ }^{138}$ KOKKORIS \& OLIVARES-CAMINAL, supra note 18, at 104.

139 Int;1 Comm. Arb. ICC Recommendations on pre-merger notifications regimes, 225/730 (March 2015), https://iccwbo.org/content/uploads/sites/3/2017/06/ICC-Recommendations-on-Pre-Merger-NotificationRegimes.pdf, 16.
} 
insolvency proceedings. In the UK, all mergers are subject to a voluntary merger regime, under Indian law, it is only some transactions that are subject to it.

\subsection{Post-merger scrutiny of green-channelled IRPs.}

There is a difference between how green-channelling affects companies that are financially distressed and ones that are profitable. For firms that are not financially distressed, entering into a merger or acquisition is a part of their strategy to grow, it is a strategy for development. ${ }^{140}$ However, an IRP is not only a strategy for growth, it is a strategy for a firm's survival, the alternative being liquidation. If an IRP is rejected before it is implemented, the $\mathrm{CoC}$ can call for new proposals or vote on the next best alternative. But if such a firm is divided after the merger; it is possible that it may not be financially stable enough to survive given its already weak position. Thus, the costs of dividing firms with dominant positions as a result of IRPs are more than the costs of dividing other firms with dominant positions. By this line of reasoning, green-channelling IRPs and subjecting them to post merger scrutiny seems counterintuitive.

Any benefits of green-channelling IRPs need to be weighed against their risks, some of which have been discussed above. Another problem with green-channelling IRPs is its potential for misuse. The threshold to trigger insolvency proceedings against a corporate debtor is not very high in India (INR 100,000). ${ }^{141}$ There is a very real possibility that groups can organise their accounts in such a manner as to intentionally make one of their divisions default. The EU has been cognizant of the possibility of such behaviour as is reflected in the limited use of the failing division defence. Whenever a failing division defence is invoked, the EC will conduct an analysis of the dealings within the groups to ensure that they were at arm's length, i.e., at uncontrolled market prices.

\section{Conclusion}

This paper set out to discern the approach of the CCI to scrutinising IRPs and whether this approach could be distilled into dependable criteria to automatically approve IRPs through the green channel. Additionally, it canvassed the EU's jurisprudence on the failing firm defence to understand how the objectives of insolvency law and competition law can be balanced. The EU's experience shows that competition scrutiny of distressed firms cannot simply be dispensed with. There are only a handful of cases in which the failing firm defence

${ }^{140} \mathrm{Id}$. at 1.

${ }^{141}$ IBC, supra note $12, \S 4$. 
was rejected, however, these decisions had significant effects on the concentrations of the relevant markets involved. As mentioned earlier in the paper, both competition law and insolvency law play important roles in the allocation of resources within the economy. Insolvency law allocates credit efficiently and competition law ensures that businesses are allowed to operate in fair market conditions. It thus follows that, sometimes, it is more beneficial to allow a firm to be liquidated and credit to be reallocated than for the firm to remain a going concern.

India is yet to see IRP combinations cause appreciable adverse effects on competition. However, this cannot not be taken as a guarantee for the nature of IRPs in the future especially given how young the new Indian insolvency regime is. From the IRPs which have come to the CCI so far, we find that they have been scrutinised by the CCI like regular mergers and a case-to-case analysis is carried out. Thus, there are no specific criteria we can discern from the CCI's approach which can be applied to IRP combinations in order to green-channel them.

The criteria in the Combination Regulation Amendments cannot be used in the context of IRPs. This is because only three out of sixteen IRPs had neither horizontal nor vertical overlaps. Some writers have suggested that the tests under the failing firm defence can be framed as questions in the self-certification form. However, this paper has shown that these tests are not always applied in a uniform fashion, rather, they are used by the competition authority to weigh the effects of the merger with those of the target business leaving the market. Such an assessment cannot be made through a self-declaration alone. Accordingly, we recommend the use of the self-certifying form described above as a tool for the merger scrutiny of IRPs but not as a substitute for the entire process. In order to balance the interests of the stakeholders of insolvency law and competition law, there can be a shorter standstill period for IRP combinations. This period can be used by the CCI to scrutinise the IRP. If the questions in the form as proposed above are answered clearly by the parties, then the scrutiny process can be considerably expedited. If the government decides to green-channel IRPs despite the risks, it must ensure that the CCI prioritizes the post-merger assessment of IRPs so as to cause the least disturbance to the stakeholders in the insolvency process in case the combination needs to be modified or prohibited. 


\section{Annexure I}

Table 1: IRP Combinations

\begin{tabular}{|c|c|c|c|c|c|}
\hline $\begin{array}{l}\text { SI. } \\
\text { No. }\end{array}$ & Order No. & $\begin{array}{l}\text { Date of } \\
\text { Order }\end{array}$ & $\begin{array}{l}\text { Type of } \\
\text { merger }\end{array}$ & Industry & $\begin{array}{ll}\text { Post-merger } & \text { market } \\
\text { concentration (\%) }\end{array}$ \\
\hline 1. & C-2018/02/557 & $\begin{array}{l}\text { Mar. } 7, \\
2018\end{array}$ & Horizontal & Cement & $0-5$ \\
\hline 2. & C-2018/02/558 & $\begin{array}{l}\text { Mar. } \\
27, \\
2018\end{array}$ & Horizontal & Cement & $20-25$ \\
\hline 3. & C-2018/03/561 & $\begin{array}{l}\text { May 11, } \\
2018\end{array}$ & Horizontal & Steel & $\begin{array}{l}\text { 20-25 (Pig Iron) } \\
\text { 5-10 (Sponge Iron) } \\
\text { 5-10 (Billets \& blooms) } \\
\text { 10-15 (TMT bars) }\end{array}$ \\
\hline 4. & C-2018/03/562 & $\begin{array}{l}\text { Apr. 25, } \\
2018\end{array}$ & $\begin{array}{l}\text { Horizontal } \\
\& \text { Vertical }\end{array}$ & Steel & $\begin{array}{l}25-30\left(\mathrm{HR}-\mathrm{CSP}^{*}\right) \\
15-20\left(\mathrm{CR}-\mathrm{CS}^{* *}\right) \\
15-20 \quad \text { (Galvanised } \\
\text { products }) \\
15-20(\mathrm{CCP} * * *) \\
20-25 \text { (Precision tubes) } \\
\text { 5-10 (Non-precision tubes) }\end{array}$ \\
\hline 5. & C-2018/04/563 & $\begin{array}{l}\text { May 11, } \\
2018\end{array}$ & $\begin{array}{l}\text { Horizontal } \\
\& \text { Vertical }\end{array}$ & $\begin{array}{l}\text { Steel } \quad \text { (Pig } \\
\text { Iron) }\end{array}$ & $\begin{array}{l}\text { Insignificant } \\
\text { percentage mentioned) }\end{array}$ \\
\hline 6. & C-2018/06/580 & $\begin{array}{l}\text { Aug. 10, } \\
2018\end{array}$ & $\begin{array}{l}\text { Horizontal } \\
\& \text { Vertical }\end{array}$ & $\begin{array}{l}\text { Edible oil \& } \\
\text { Wind Energy }\end{array}$ & $\begin{array}{l}\text { 0-5 (Wind energy) } \\
\text { Combined market share } \\
\text { for edible oils was not } \\
\text { mentioned. }\end{array}$ \\
\hline 7. & C-2018/08/593 & $\begin{array}{l}\text { Sep. 18, } \\
2018\end{array}$ & $\begin{array}{l}\text { Horizontal } \\
\& \text { Vertical }\end{array}$ & Steel & Less than 20 \\
\hline 8. & C-2018/08/594 & $\begin{array}{l}\text { Sep. 18, } \\
2018\end{array}$ & $\begin{array}{l}\text { Horizontal } \\
\text { \& Vertical }\end{array}$ & Steel & $\begin{array}{l}\begin{array}{l}\text { Less than } 30 \\
\text { CR-CS, HR-CSPs, } \\
\text { galvanized }\end{array} \\
\text { products, tubes \& pipes). } \\
30-35 \quad \text { (colour coated } \\
\text { products) }\end{array}$ \\
\hline 9. & C-2018/09/599 & $\begin{array}{l}\text { Nov. } 6, \\
2018\end{array}$ & $\begin{array}{l}\text { Horizontal } \\
\text { \& Vertical }\end{array}$ & $\begin{array}{l}\text { Steel/auto- } \\
\text { parts }\end{array}$ & 20-25 (connecting rods) \\
\hline 10. & C-2018/12/624 & $\begin{array}{l}\text { Jan. 10, } \\
2019\end{array}$ & Vertical & Construction & NA \\
\hline 11. & C-2019/01/631 & $\begin{array}{l}\text { Mar. 6, } \\
2019\end{array}$ & $\begin{array}{l}\text { Horizontal } \\
\& \text { Vertical }\end{array}$ & Edible oil & $\begin{array}{l}\text { Insignificant } \\
\text { percentage mentioned) }\end{array}$ \\
\hline
\end{tabular}




\begin{tabular}{|c|c|c|c|c|c|}
\hline 12. & C-2019/01/632 & $\begin{array}{l}31 \text { Jan. } \\
2019\end{array}$ & No overlap & Construction & NA \\
\hline 13. & C-2019/02/642 & $\begin{array}{l}\text { Mar. } 7 \text {, } \\
2019\end{array}$ & No overlap & Telecom & NA \\
\hline 14. & C-2019/03/650 & $\begin{array}{l}\text { Apr. 9, } \\
2019\end{array}$ & $\begin{array}{l}\text { Horizontal } \\
\& \text { Vertical }\end{array}$ & Steel & 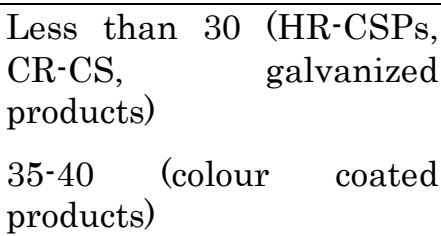 \\
\hline 15. & C-2018/07/581 & $\begin{array}{l}\text { Aug. 6, } \\
2018\end{array}$ & $\begin{array}{l}\text { Horizontal } \\
\& \text { Vertical }\end{array}$ & Steel & 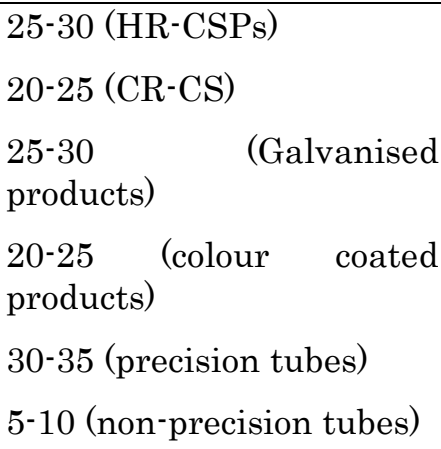 \\
\hline 16. & C-2019/04/659 & $\begin{array}{l}\text { Jun. 3, } \\
2019\end{array}$ & No overlap & Steel & N/A \\
\hline
\end{tabular}

*Hot rolled coils, sheets and pipes

$* *$ Cold rolled coils and sheets

$* * *$ Colour coated pipes

\section{Table 2: Regular Combinations}

\begin{tabular}{|l|l|l|l|l|l|}
\hline $\begin{array}{l}\text { SI. } \\
\text { No. }\end{array}$ & Order No. & Date & $\begin{array}{l}\text { Type of } \\
\text { merger }\end{array}$ & Industry & $\begin{array}{l}\text { Post-merger } \\
\text { concentration (\%) }\end{array}$ \\
\hline 1. & $\begin{array}{l}\text { No. C- } \\
2017 / 12 / 539\end{array}$ & $\begin{array}{l}\text { Jan. } \\
22, \\
2018 .\end{array}$ & Vertical & Steel & $\begin{array}{l}\text { Not likely to raise competition } \\
\text { concerns (No market share } \\
\text { mentioned. }\end{array}$ \\
\hline 2. & $\begin{array}{l}\text { No. C- } \\
2017 / 04 / 503\end{array}$ & $\begin{array}{l}\text { Jun. 8, } \\
2017\end{array}$ & $\begin{array}{l}\text { Horizontal } \\
\text { \& Vertical }\end{array}$ & Steel & $\begin{array}{l}\text { Insignificant (No market } \\
\text { share mentioned). }\end{array}$ \\
\hline 3. & $\begin{array}{l}\text { No. C- } \\
2018 / 09 / 597\end{array}$ & $\begin{array}{l}\text { Nov. } \\
30, \\
2018\end{array}$ & Horizontal & Steel & $\begin{array}{l}\text { Specialty steel bars (15-20) } \\
\text { Seamless pipes (0-5) }\end{array}$ \\
\hline 4. & $\begin{array}{l}\text { No. C- } \\
2015 / 10 / 329)\end{array}$ & $\begin{array}{l}\text { Dec. } \\
30, \\
2015\end{array}$ & $\begin{array}{l}\text { Horizontal } \\
\text { \& Vertical }\end{array}$ & Steel & Special Steel (0-10) \\
\hline 5. & $\begin{array}{l}\text { No. C- } \\
2015 / 06 / 287\end{array}$ & $\begin{array}{l}\text { Aug. } \\
19, \\
2015\end{array}$ & $\begin{array}{l}\text { Horizontal } \\
\text { \&Vertical }\end{array}$ & $\begin{array}{l}\text { Steel (for the } \\
\text { tower } \\
\text { manufacturing } \\
\text { business) }\end{array}$ & $\begin{array}{l}\text { Insignificant (no percentage } \\
\text { mentioned) }\end{array}$ \\
\hline 6. & $\begin{array}{l}\text { Combination } \\
\text { Registration No. } \\
\text { C-2018/10/608 }\end{array}$ & $\begin{array}{l}\text { Dec. 7, } \\
2018\end{array}$ & $\begin{array}{l}\text { Horizontal } \\
\text { \& Vertical }\end{array}$ & Steel & Less than 20 \\
\hline
\end{tabular}




\begin{tabular}{|l|l|l|l|l|l|}
\hline 7. & $\begin{array}{l}\text { Combination } \\
\text { Registration No. } \\
\text { C-2016/10/447 }\end{array}$ & $\begin{array}{l}\text { Dec. } \\
20, \\
2016 .\end{array}$ & Vertical & $\begin{array}{l}\text { Steel (for the } \\
\text { manufacture } \\
\text { of automotive } \\
\text { parts) }\end{array}$ & $\begin{array}{l}\text { Insignificant (no percentage } \\
\text { mentioned) }\end{array}$ \\
\hline 8. & $\begin{array}{l}\text { No. C- } \\
2018 / 05 / 575\end{array}$ & $\begin{array}{l}\text { Aug. } \\
21, \\
2018\end{array}$ & Horizontal & Cement & $\begin{array}{l}\text { Maharashtra (20, HHI delta: } \\
120) \\
\text { Madhya Pradesh (28, HHI } \\
\text { delta 164) } \\
\text { Chhattisgarh/West Bengal } \\
\text { (22, HHI delta: 186) }\end{array}$ \\
\hline 9. & $\begin{array}{l}\text { No. C- } \\
2016 / 04 / 394\end{array}$ & $\begin{array}{l}\text { Apr. } 4, \\
2018\end{array}$ & Horizontal & Cement & $\begin{array}{l}\text { Andhra Pradesh (16, HHI } \\
\text { delta: 65) } \\
\text { Uttar Pradesh/Madhya } \\
\text { Pradesh (21, HHI delta: 122) } \\
\text { Uttarakhand (22, HHI delta: } \\
126) \\
\text { Himachal Pradesh (30, HHI } \\
\text { delta: 400) }\end{array}$ \\
\hline
\end{tabular}

